\title{
Persistence of Complex Virulences in Populations of Phytophthora infestans in Western Washington
}

\author{
M. L. Derie and D. A. Inglis
}

Washington State University-Mount Vernon Research and Extension Unit, 16650 State Route 536, Mount Vernon 98273. Accepted for publication 26 March 2001.

\begin{abstract}
Derie, M. L., and Inglis, D. A. 2001. Persistence of complex virulences in populations of Phytophthora infestans in western Washington. Phytopathology 91:606-612.

Isolates of Phytophthora infestans, collected from bittersweet, hairy nightshade, petunia, potato, potato vine, and tomato in western Washington, 1998 to 1999 , were evaluated for virulence complexity as well as mating type, metalaxyl insensitivity, allozymes of glucose-6-phosphate isomerase and peptidase, and DNA fingerprint with the RG57 probe. Results were compared with those from similar collections made in the same region during the 1990s. Generally, virulence complexity was high for most of the isolates regardless of year, genotype, or host. No marked shift in viru-

virulences were maintained. During 1998 and 1999, isolates of the US-8 and US-11 genotypes had 4 or more virulence factors. US- 8 isolates averaged 8.2 and 9.3, whereas US-11 isolates averaged 5.4 and 6.3 virulence factors. The frequency of US- 8 isolates that were sensitive to metalaxyl ranged from 5\% in 1998 to $72 \%$ in 1999. All of the US-11 isolates tested in 1998 and 1999 were insensitive to metalaxyl. From 1996 to 1999 on potato, the recovery of US-8 increased, whereas the recovery of US-11 decreased. No evidence of new genotypes or sexual recombination was found. Western Washington was a desirable location for screening germ plasm for durable resistance to late blight due to the high frequency and persistence of complex virulences.
\end{abstract} lence complexity was evident for the populations studied, and unnecessary
Additional keyword: host resistance.
Complex virulences in populations of Phytophthora infestans (Mont.) de Bary have been variously defined and documented worldwide since the 1960 s $(3,12,26,41,43,44,50,51,54)$. Generally, the term complex virulence encompasses those isolates carrying more than one virulence gene (55). Many of the new immigrant populations of $P$. infestans now found in many potato and tomato production regions $(1,8,10,13,22,24,48)$ are characterized by virulence complexity.

The high variability in $P$. infestans populations throughout the world, especially for virulence, has made race-specific resistance genes almost useless in disease control $(1,46,57)$. As early as 1849, Solanum demissum was used in attempts to develop late blight resistant germ plasm $(34,42,55)$. However, over the next 100 years the succession of hybrids made primarily between $S$. tuberosum and the Mexican hexaploid species, S. demissum, failed to be reliable. Realization that most $S$. demissum-derived resistance was due to resistance genes (R-genes) that were easily defeated by compatible $P$. infestans led to general abandonment of an R-gene strategy for late blight control. Nonetheless, most of the potato breeding programs of the 20th century have incorporated $S$. demissum to some degree in the background of their materials. Non-R-gene-based resistance extracted from $S$. demissum continues to be a basis of stable horizontal resistance for some modern breeding clones and cultivars $(39,40)$. By the mid-1950s, four single R-genes from $S$. demissum were identified by Black et al. (2); seven others have subsequently been identified $(36,42,57)$. At least 16 distinct R-genes now are known to exist in $S$. demissum (39), and 11 of these have been introgressed into $S$. tuberosum $(11,35)$. Even so, according to Fry and Goodwin (14), a majority of potato acreage in western Europe is planted to cultivars without

Corresponding author: D. A. Inglis; E-mail address: dainglis@wsu.edu

Publication no. P-2001-0413-01R

(C) 2001 The American Phytopathological Society
R-genes, and a majority of potato cultivars grown in the United States and Canada contain no known R-genes.

In an analysis of isolates of $P$. infestans collected worldwide from 1966 to 1993, Andrivon (1) found that unnecessary virulences were frequent in most, if not all, populations of $P$. infestans. Races of $P$. infestans containing as many as nine virulence factors have been found repeatedly throughout Europe, and most of these complex races are very aggressive (53). However, in the U.S. isolates of the new clonal lineages representing US-6 and US-8 genotypes of $P$. infestans appeared to lose pathogenicity to many R-genes over a 2-year period (22). Van der Plank's (56) theory of stabilizing selection asserts that races with the minimum number of unnecessary virulence genes are the most fit, and thus, the most likely to survive. In a study of asexual and sexual populations of $P$. infestans, isolates with extra or unnecessary virulence genes were not found to be less fit on simple host genotypes (those containing few or no R-genes) (51).

Epidemics of late blight on potato occur annually west of the Cascade Mountains in western Washington where the temperate, marine climate is highly favorable for disease development (8). Complex virulence among western Washington isolates of $P$. infestans was first reported in 1990 by Deahl et al. (6) when metalaxyl-insensitive isolates collected in the region displayed a high frequency of complex race combinations; 53\% had three or more virulence factors on the seven resistance genes tested (R0 disregarded). Isolates of $P$. infestans collected from the United States and Canada during 1989 to 1994, including eight isolates from western Washington, were studied by Goodwin et al. (22). Of 57 isolates representing new immigrant genotypes, over $80 \%$ were virulent to four or more potato resistance genes of the nine tested. Among the western Washington isolates, one isolate carried three virulence factors, whereas the other isolates carried four, seven, or eight virulence factors. Dorrance et al. (8) evaluated isolates of $P$. infestans from western Washington for pathogenicity phenotype; $90 \%$ in 1996 and $80 \%$ in 1997 infected four or more of the 10 potato differentials tested. 
As with other areas of the U.S., western Washington has been subject to migrations of new and aggressive genotypes of $P$. infestans that are insensitive to metalaxyl. These genotypes have displaced the older lineages of $P$. infestans. In western Washington, the US-6 genotype (A1 mating type) sensu Goodwin et al. (20) was detected during 1990 and 1991 (21). In 1994, a previously undescribed genotype, US-11 (also A1 mating type) sensu Goodwin et al. (20), was reported $(14,20,30)$ which completely displaced US-6 by 1996 (8). In 1997, US-7, US-8, and US-14 genotypes sensu Goodwin et al. (20), were detected, representing the first known occurrences of the A2 mating type in western Washington, presenting the potential for sexual recombination (8).

Identification of the virulence pathotypes of the $P$. infestans isolates used to evaluate potato germ plasm and cultivars for late blight resistance is extremely important (24). The presence of Rgenes can mask race nonspecific or durable types of resistance unless the disease screen utilizes a broad range of the known races of the pathogen (45). Because we are interested in field disease screens, which increase the likelihood of selecting for durable resistance, and thereby, involve a broad range of the known pathotypes of $P$. infestans, an evaluation of the persistence of complex virulences in western Washington populations of $P$. infestans was the objective of this study. A preliminary report (7) has been published.

\section{MATERIALS AND METHODS}

Sources of isolates and culture of $\boldsymbol{P}$. infestans. Samples of infected plant material were collected from commercial potato fields, research plots, greenhouses, home gardens, and volunteer plants and weeds in western Washington counties west of the Cascade mountain range in 1998 and 1999. The majority (96\%) of the isolates were collected from samples obtained at or near (within a 16-km radius) the Washington State University-Mount Vernon Research and Extension Unit (WSU-Mount Vernon REU), which is located central to approximately $80 \%$ of western Washington's commercial potato acreage. Plant material included bittersweet $(S$. dulcamara), hairy nightshade (S. sarachoides), petunia (Petunia hybrida), potato (S. tuberosum), potato vine (S. crispum), tomato (Lycopersicon esculentum), and red and yellow currant tomato $(L$. pimpinellifolium). In addition, isolates were collected from potato differentials PI 423651 (R1), PI 423652 (R2), PI 423653 (R3), PI 203900 (R4), PI 303146 (R5), PI 587059 (R6), PI 303148 (R7), PI 303149 (R8), LB 1 (R9), PI 423656 (R10), and PI 587060 (R11), which were planted at the experiment station in both 1998 and 1999.

Isolation of $P$. infestans from discreet foliar, stem, tuber, or fruit lesions followed techniques described or cited in Dorrance et al. (8), except sterile, moistened, filter paper strips $(\approx 3 \times 15 \mathrm{~mm})$ were used to transfer sporangia from sporulating lesions to rye agar. One to twelve plants were sampled per collection site, and one to three isolations were made per plant sample. Long-term maintenance of isolates was on slants of rye agar plus sucrose at $10^{\circ} \mathrm{C}$ under sterile mineral oil (52).

Characterization of isolates. All isolates were characterized for genotype at the two allozyme loci, glucose-6-phosphate isomerase (Gpi) (EC 5.3.1.9) and peptidase (EC 3.4.3.1), and mating type, following techniques described previously (8). The peptidase locus was included to potentially differentiate genotypes known to exist in the region from genotypes not previously encountered. Subsets of isolates were tested for pathogenicity phenotype, DNA fingerprint, and metalaxyl sensitivity, and were selected based on host origin, location, and allozyme genotype.

The subset analyzed for pathogenicity phenotype against 10 or 11 single R-gene potato differentials (R1 to 11) in the laboratory included 49 isolates collected during 1998 and 1999. Virulence assays were performed by placing two leaflets of each differential plant abaxial side up in inverted petri dishes containing water agar
$(8,51)$. Cultivar Russet Norkotah was used as a susceptible control. There were two replicates per isolate for a total of four leaflets. Sporangial suspensions were generated from incubated leaflets of cv. Russet Norkotah inoculated 5 to 7 days previously with the test isolates. Each leaflet was inoculated with a 50- $\mu$ l droplet containing $2.5 \times 10^{4}$ sporangia per ml. Leaflets were incubated in a growth chamber set at $18^{\circ} \mathrm{C}$ with a $12 \mathrm{~h}$ light/dark cycle. After 7 days, leaflets were scored for the presence or absence of sporulation by $P$. infestans. Every isolate was assayed at least twice, and only those tests in which the majority of leaflets $(\geq 3$ of 4$)$ of a differential reacted the same were included. An octal nomenclature system was used in summarizing the virulence data set. As described by Goodwin et al. (22), the first octal digit reflects the score of the three potato R-gene differentials, R1, R2, and R3. A compatible reaction with a single differential is scored a 1 , and 0 is given for an incompatible reaction. The three-digit code is transformed into an octal number with values from 0 to 7 with $0=$ $000 ; 1=001 ; 2=010 ; 3=011 ; 4=100 ; 5=101 ; 6=110$; and $7=$ 111. Missing data were counted as 0 and octal digits were underlined to reflect the missing value. The second, third, and fourth octal digits reflect the scores of R4 to R6, R7 to R9, and R10 and $\mathrm{R} 11$, respectively.

A subset of 70 isolates was analyzed for nuclear DNA fingerprint by the highly polymorphic, moderately repetitive DNA probe RG57 (19). Forty-seven isolates were collected between 1998 and 1999; the remaining isolates were originally collected and partially characterized by Dorrance et al. (8). The standards used for comparisons included representatives of the US-1, US-8, and US11 genotypes. Mycelia for DNA extraction was obtained by inoculating 90-mm-diameter petri dishes of rye broth medium with two rye agar plugs from actively growing cultures of each test isolate. The plates were incubated at $18^{\circ} \mathrm{C}$ for 7 to 14 days, and mycelia from two to four plates were harvested by vacuum filtration of the broth through a Buchner funnel lined with Whatman No. 1 filter paper (Clifton, NJ) (W. E. Fry, personal communication). DNA was extracted immediately or the mycelium was stored at $-20^{\circ} \mathrm{C}$ until use. Extraction and digestion of DNA with restriction enzyme EcoRI followed the protocol outlined in Dorrance et al. (8). Southern transfer to Hybond $\mathrm{N}+$ nylon membranes (Amersham Life Science, Arlington Heights, IL) was based on the procedure described by Weising et al. (58), except gels were depurinated in $0.25 \mathrm{M} \mathrm{HCl}$ for $10 \mathrm{~min}$ prior to denaturization. Labeling, hybridization, and detection of the probe was done using the Renaissance random primer fluorescein labeling kit with antiflourescein-AP (NEN Life Science Products, Boston) following the manufacturer's instructions, except that stringency washes following hybridization were extended $5 \mathrm{~min}$ and the second wash step was performed at $65^{\circ} \mathrm{C}$ (W. E. Fry, personal communication).

The subset tested for metalaxyl sensitivity included 55 isolates collected in 1998 and the 51 isolates collected in 1999. Sensitivity tests were done with metalaxyl-amended agar media (8). Isolates that grew at more than $40 \%$ of the control on $5 \mu \mathrm{g} / \mathrm{ml}$ of metalaxyl-amended medium were rated metalaxyl insensitive.

Results of virulence assays, allozyme analysis, mating type, and metalaxyl sensitivity assays of isolates collected in 1998 and 1999 were compared with those of collections made in 1996 and 1997 (8). Virulence complexity was assessed from pathogenicity phenotype analysis. An isolate was defined as complex if it carried $\geq 4$ virulence factors. DNA fingerprint data was used to confirm genotypes identified initially by allozyme analysis and mating type. The number of isolates of the most predominant genotypes recovered by host was determined for each year.

\section{RESULTS}

The 1998 collection. One hundred eighteen isolates of $P$. infestans were collected from potato, tomato, and hairy nightshade in 
1998 (Table 1). Four genotypes, based on allozyme analysis and mating type, were detected: US-7, US-8, US-11, and US-14. Two very complex pathogenicity phenotypes were found among the US- 8 isolates and they displayed 8 or 9 virulence factors with an average of 8.2 (Table 2). The US-11 isolates comprised three pathogenicity phenotypes with 4,5 , or 6 virulence factors and an average of 5.4 (Table 2). Both mating types were found on potato as well as tomato (Table 1) but not on the same plant. All of the isolates were metalaxyl insensitive except for two US-8 isolates (Fig. 1) that were rated sensitive. Recovery from potato was greater for US-8 than for US-11 (Fig. 2; Table 1).

The 1999 collection. Fifty-one isolates were collected in 1999 from eight hosts (Table 1). Only US-8 and US-11 genotypes were detected. Virulence assays revealed three pathogenicity phenotypes in isolates of US-8, carrying 9, 10, or 11 virulence factors with an average of 9.3 . US-11 had four pathogenicity phenotypes with $5,6,7$, or 9 virulence factors averaging 6.3 (Table 2). Both mating types were found on potato, tomato, and petunia at a single location, but not on the same plant. Of the US- 8 isolates, 21 of 29 grew less than $40 \%$ of the control on $5 \mu \mathrm{g} / \mathrm{ml}$ of metalaxyl medium and were rated metalaxyl sensitive (Fig. 1). In contrast, all of the US-11 isolates were metalaxyl insensitive. US-8 was the predominant genotype recovered from potato (Fig. 2; Table 1).

DNA fingerprint analyses. DNA fingerprints (Fig. 3) confirmed genotype identifications made by allozyme analysis and mating type, except for one isolate previously identified as US-7 in 1998. This isolate had a DNA fingerprint identical to US-8 (Fig. 3), and was considered a somatic variant of US-8 through loss of the Gpi 122 allele, similar to US-14 (Gpi 100/122), which is theorized to be a somatic variant through loss of the Gpi 111 allele (20). The US-1 genotype standard did not show band 9 in the fingerprints (Fig. 3). However, this isolate originally displayed the band in earlier DNA fingerprints (8). It may have lost the band in repeated culture transfers over time. Although both mating types (Table 1) were found in close proximity on the same or neighboring hosts, no evidence of new genotypes or sexual recom-

TABLE 1. Characteristics of Phytophthora infestans isolates collected in western Washington during 1998 to 1999

\begin{tabular}{|c|c|c|c|c|c|c|}
\hline Year & Genotype $^{a}$ & Host $^{b}$ & $\begin{array}{l}\text { No. of } \\
\text { isolates }\end{array}$ & $G p i^{\mathrm{c}}$ & $P e p^{\mathrm{d}}$ & $\begin{array}{l}\text { Mating } \\
\text { type }^{\mathrm{e}}\end{array}$ \\
\hline \multirow[t]{7}{*}{1998} & US- $7^{f}$ & Potato & 1 & $100 / 111$ & $100 / 100$ & $\mathrm{~A} 2$ \\
\hline & US-8 & Hairy nightshade & 2 & $100 / 111 / 122$ & $100 / 100$ & $\mathrm{~A} 2$ \\
\hline & & Potato & 80 & & & \\
\hline & & Tomato & 3 & & & \\
\hline & US-11 & Potato & 12 & $100 / 100 / 111$ & $100 / 100$ & A1 \\
\hline & & Tomato & 18 & & & \\
\hline & US-14 & Potato & 2 & $100 / 122$ & $100 / 100$ & $\mathrm{~A} 2$ \\
\hline \multirow[t]{11}{*}{1999} & US-8 & Petunia & 1 & $100 / 111 / 122$ & $100 / 100$ & A2 \\
\hline & & Potato & 23 & & & \\
\hline & & Tomato & 5 & & & \\
\hline & US-11 & Bittersweet & 1 & $100 / 100 / 111$ & $100 / 100$ & $\mathrm{~A} 1$ \\
\hline & & Hairy nightshade & 1 & & & \\
\hline & & Petunia & 2 & & & \\
\hline & & Potato & 6 & & & \\
\hline & & Potato vine & 1 & & & \\
\hline & & Red currant & 1 & & & \\
\hline & & Tomato & 9 & & & \\
\hline & & Yellow currant & 1 & & & \\
\hline
\end{tabular}

a U.S. genotype designations sensu Goodwin et. al. (20).

${ }^{\mathrm{b}}$ Bittersweet $=$ Solanum dulcamara $;$ hairy nightshade $=$ S. sarachoides ; petunia $=$ Petunia hybrida , potato vine $=S$. crispum , and red and yellow currant tomato $=$ Lycopersicon pimpinellifolium.

${ }^{c}$ Glucose-6-phosphate isomerase.

${ }^{\mathrm{d}}$ Peptidase.

${ }^{\mathrm{e}}$ Determined by pairing against known mating type isolates on rye agar medium.

${ }^{\mathrm{f}}$ Likely a US- 8 variant (US-7 by allozyme analysis but US- 8 by DNA fingerprint). bination was found in the region by either allozyme analysis (Table 1) or DNA fingerprint (Fig. 3).

Changes in western Washington $P$. infestans populations over time. Virulence complexity generally was high for most of the isolates collected in western Washington regardless of the year they were collected, the genotype they represented, or the host from which they were recovered (Tables 2 and 3). Ninety percent of the tested US-11 isolates had 4 or more virulence factors in 1996 (8; Table 3). In 1997 (8; Table 3), 100\% of US-8 isolates and $73 \%$ of US-11 isolates had 4 or more virulence factors. Fifty percent of less of the isolates from tomato in 1997 had $\leq 4$ virulence factors (Table 3). Altogether, in 1998 and 1999 (Tables 2 and 3), all of the US-8 and US-11 isolates tested, respectively, had 4 or more virulence factors. In addition, the isolates recovered from solanaceous hosts other than potato or tomato had 6 or more virulence factors (8; Table 3 ). Of the potato differentials planted in the field from 1997 (8) to 1999, only the R8 and R9 differentials were symptomless, except in 1998, when they were diseased. Isolates collected from R8 and R9 potato plants in 1998 were later rated noncompatible in the laboratory with detached leaflets of the potato R-gene differentials, R8 and R9.

TABLE 2. Pathogenicity phenotypes among a subset of 49 isolates of Phytophthora infestans collected in western Washington during 1998 to 1999

\begin{tabular}{|c|c|c|c|c|c|c|}
\hline Year & Genotype $^{\mathrm{a}}$ & $\operatorname{Host}^{\mathrm{b}}$ & $\begin{array}{l}\text { No. of } \\
\text { isolates }\end{array}$ & Phenotype $^{c}$ & Octal $^{\mathrm{d}}$ v & $\begin{array}{l}\text { Avg.e } \\
\text { virulence }\end{array}$ \\
\hline \multirow[t]{15}{*}{1998} & US- $7^{f}$ & Potato & 1 & $1,2,3,4,5,6,7,10$ & $7,7,4, \underline{4}$ & 8.0 \\
\hline & US-8 & $\begin{array}{l}\text { Hairy } \\
\text { nightshade }\end{array}$ & 1 & 123456710 & 77.4 .4 & \\
\hline & & Potato & 12 & $1,2,3,4,5,6,7,10$ & $7,7,4, \underline{4}$ & \\
\hline & & Potato & 1 & $1,2,3,4,5,6,7,10$ & $7,7,4,4$ & \\
\hline & & Potato & 4 & $1,2,3,4,5,6,7,10,11$ & $7,7,4,6$ & \\
\hline & & Tomato & 1 & $1,2,3,4,5,6,7,10$ & $7,7,4, \underline{4}$ & \\
\hline & Total & & 19 & & & 8.2 \\
\hline & US-11 & Potato & 1 & $1,5,6,7$ & $4,3,4,0$ & \\
\hline & & Potato & 1 & $1,5,6,7$ & $4,3,4, \underline{0}$ & \\
\hline & & Potato & 1 & $1,2,4,5,6,7$ & $6,7,4, \overline{0}$ & \\
\hline & & Potato & 3 & $1,2,4,5,6,7$ & $6,7,4, \underline{0}$ & \\
\hline & & Tomato & 1 & $1,4,5,6,7$ & $4,7,4, \underline{0}$ & \\
\hline & & Tomato & 2 & $1,2,4,5,6,7$ & $6,7,4, \underline{0}$ & \\
\hline & Total & & 9 & & & 5.4 \\
\hline & US-14 & Potato & 1 & $1,2,3,4,5,6,7,10$ & $7,7,4, \underline{4}$ & 8.0 \\
\hline \multirow[t]{16}{*}{1999} & US-8 & Petunia & 1 & $1,2,3,4,5,6,7,10,11$ & $7,7,4,6$ & \\
\hline & & Potato & 5 & $1,2,3,4,5,6,7,10,11$ & $7,7,4,6$ & \\
\hline & & Potato & 1 & $1,2,3,4,5,6,7,8,9,10,11$ & $7,7,7,6$ & \\
\hline & & Tomato & 2 & $1,2,3,4,5,6,7,10,11$ & $7,7,4,6$ & \\
\hline & & Tomato & 1 & $1,2,3,4,5,6,7,8,10,11$ & $7,7,6,6$ & \\
\hline & Total & & 10 & & & 9.3 \\
\hline & US-11 & Bittersweet & 1 & $1,2,4,5,6,7$ & $6,7,4,0$ & \\
\hline & & $\begin{array}{l}\text { Hairy } \\
\text { nightshade }\end{array}$ & 1 & $1,2,4,5,6$ & $6,7,4,0$ & \\
\hline & & Petunia & 1 & $1,2,3,4,5,6,7$ & $7,7,4,0$ & \\
\hline & & Potato & 1 & $1,2,4,5,7$ & $6,6,4,0$ & \\
\hline & & Potato vine & 1 & $1,2,3,4,5,6,7,10,11$ & $7,7,4,6$ & \\
\hline & & Tomato & 1 & $1,2,4,5,7$ & $6,6,4,0$ & \\
\hline & & Tomato & 1 & $1,2,4,5,6,7$ & $6,7,4,0$ & \\
\hline & & Tomato & 1 & $1,2,3,4,5,6,7$ & $7,7,4,0$ & \\
\hline & & $\begin{array}{l}\text { Yellow } \\
\text { currant }\end{array}$ & 1 & $1,2,4,5,6,7$ & $6,7,4,0$ & \\
\hline & Total & & 9 & & & 6.3 \\
\hline
\end{tabular}

${ }^{a}$ U.S. genotype designations sensu Goodwin et al. (20).

${ }^{\mathrm{b}}$ Bittersweet $=$ Solanum dulcamara , hairy nightshade $=S$. sarrachoides; petunia $=$ Petunia hybrida , potato vine $=S$. crispum , and yellow currant tomato $=$ Lycopersicon pimpinellifolium.

${ }^{c}$ Summary of two or more detached potato leaflet assays using inverted water agar dishes as described by Dorrance et al. (8), and Tooley et al. (51).

d The R11 potato differential was not available for every detached leaflet test; the corresponding octal digits (22) were underlined to reflect the missing data.

e Average number of virulence factors.

${ }^{\mathrm{f}}$ Likely a US-8 variant (US-7 by allozyme analysis but US-8 by DNA fingerprint). 
No metalaxyl sensitive isolates of $P$. infestans were detected in 1996 or 1997 (8). However, in 1998, 5\% of the US-8 isolates were metalaxyl sensitive whereas $72 \%$ were metalaxyl sensitive in 1999. All isolates of the US-11 lineage were metalaxyl insensitive in 1998 and 1999 (Fig. 1). The percent recovery of US-8 and US11 from potato and tomato between 1996 and 1999 is shown in Figure 2. There was a decline in the recovery of US-11 on potato combined with increasing recovery of US-8 on potato over these 4 years. US-11 was the only genotype recovered from tomato until 1998, when US-8 was detected in tomato research plots at the experiment station. Both genotypes were recovered from tomato in 1999 but US-11 again predominated on tomato at the experiment station.

\section{DISCUSSION}

Complex virulences among US-8 and US-11 isolates of $P$. infestans within a localized commercial potato production region of the United States persisted over an extended period. As in other areas of the world (55), the capacity of P. infestans to form and maintain races with complex virulences in western Washington may be greater than previously known. Isolates with complex virulences were first documented in western Washington in the early 1990s (6,22) and again in 1996 and 1997 (8). Complexity was maintained through 1999. Generally, virulence complexity was high among isolates across years, genotype, and host. The persistence of complex pathotypes in populations of $P$. infestans could be due to one or more factors: (i) capacity to maintain unnecessary virulence genes $(15,55)$; (ii) mutation or recombi- nation in race evolution $(1,15,22)$; and (iii) migration of new and complex genotypes into production regions $(18,20,22)$.

According to Van der Plank (56), unnecessary virulences place a genetic load on the pathogen, and therefore make it less fit to compete with simple races. However, the results of this study indicate that western Washington populations of $P$. infestans do not appear to be rapidly losing unnecessary virulence genes. Complex pathotypes have been detected in migrant genotypes of $P$. infestans at other locations $(1,10,22)$. These genotypes have quickly displaced resident populations containing simpler pathotypes, implying that migrant genotypes carry a large fitness advantage. Goodwin (17) suggested three mechanisms for the fitness advantage: (i) the migrants recently came from sexually reproducing populations in Mexico; (ii) a large mutational load was present in the resident asexual populations as theorized by the Muller's ratchet hypothesis (38); and (iii) genetic bottlenecks alone causing the reduced fitness of the resident populations.

Allozyme analysis and DNA fingerprints of the isolates in this study provide no evidence of sexual recombination. A1 and A2 mating types have been detected in western Washington since 1997 , sometimes in the same field and in one case from the same plant (8). Possible recombinants were detected in British Columbia in 1992 (21) and the Columbia Basin of Oregon and Washington in 1993 (16). Goodwin et al. (20) proposed that US11 is likely a sexual recombinant, possibly from pairings of US-6 with US-7 or US-8. Gavino et al. (16) crossed parental strains of US-6 and US-7 in the laboratory and analyzed genetic markers in isolates collected in 1993 from the Columbia Basin, concluding US-11 was generated there. US-11 was first detected in
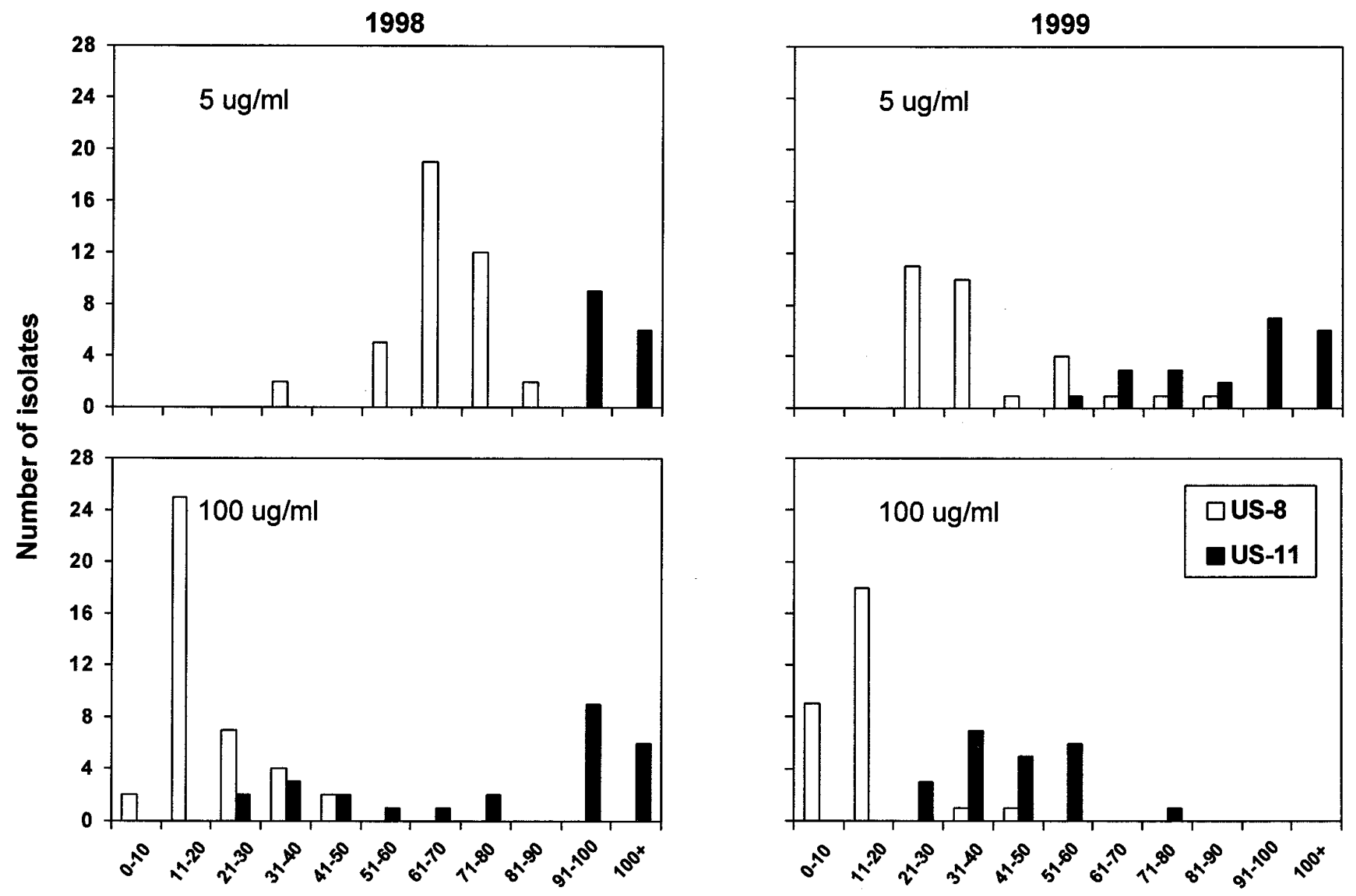

Percent growth of control

Fig. 1. Relative growth on metalaxyl-amended agar media of 55 and 51 isolates of the US-8 and US-11 genotypes of Phytophthora infestans, respectively, collected in western Washington during 1998 to 1999. Radial growth is expressed as percentage of the growth on agar medium with $0 \mu \mathrm{g}$ of metalaxyl per ml. 
western Washington in 1994 , but it most probably was the result of a migration event (8). The introduction of A2 mating types into other countries has led to sexually reproducing populations $(10,47)$. However, there are other areas in the world where both mating types apparently coexist (Japan and Korea) with no evidence of sexual recombination (33). Mosa et al. (37) reported that oospores from pairings of Asian A1 and A2 isolates did not germinate. Attempts to germinate oospores generated from pairings of US-8 and US-11 isolates in our laboratory have failed so far.

In western Washington, migration events of new genotypes have been well documented $(6,8,22)$. An important characteristic of the new immigrant populations is insensitivity to metalaxyl. Metalaxyl sensitivity, as measured by growth on metalaxylamended agar media, increased from 0 to $72 \%$ for isolates of US8 between 1997 and 1999. Daayf and Platt (5) found increasing sensitivity to metalaxyl among US-8 $P$. infestans isolates collected in Canada in 1997 and 1998 using amended agar assays. It has been suggested that the US-8 genotype is heterozygous for metalaxyl sensitivity and US-11 is homozygous for insensitivity (23), and this may explain the diversity in insensitivity to metalaxyl among genotypes (5). Kadish and Cohen (32) suggested that metalaxyl-insensitive isolates may not survive as well in tubers as metalaxyl-sensitive isolates, which offers an additional explanation for the rising levels of metalaxyl sensitivity in the US-8 lineage. Goodwin et al. (20) found in comparisons with floating leaf assays that isolates of US-8 grew slowly on metalaxylamended agar but grew at almost $100 \%$ of the control in floating leaf assays, and suggested that the floating leaf assay may be more predictive of response to metalaxyl in the field. Thus, there is some question as to the accuracy of metalaxyl-amended agar assays to predict metalaxyl sensitivity.

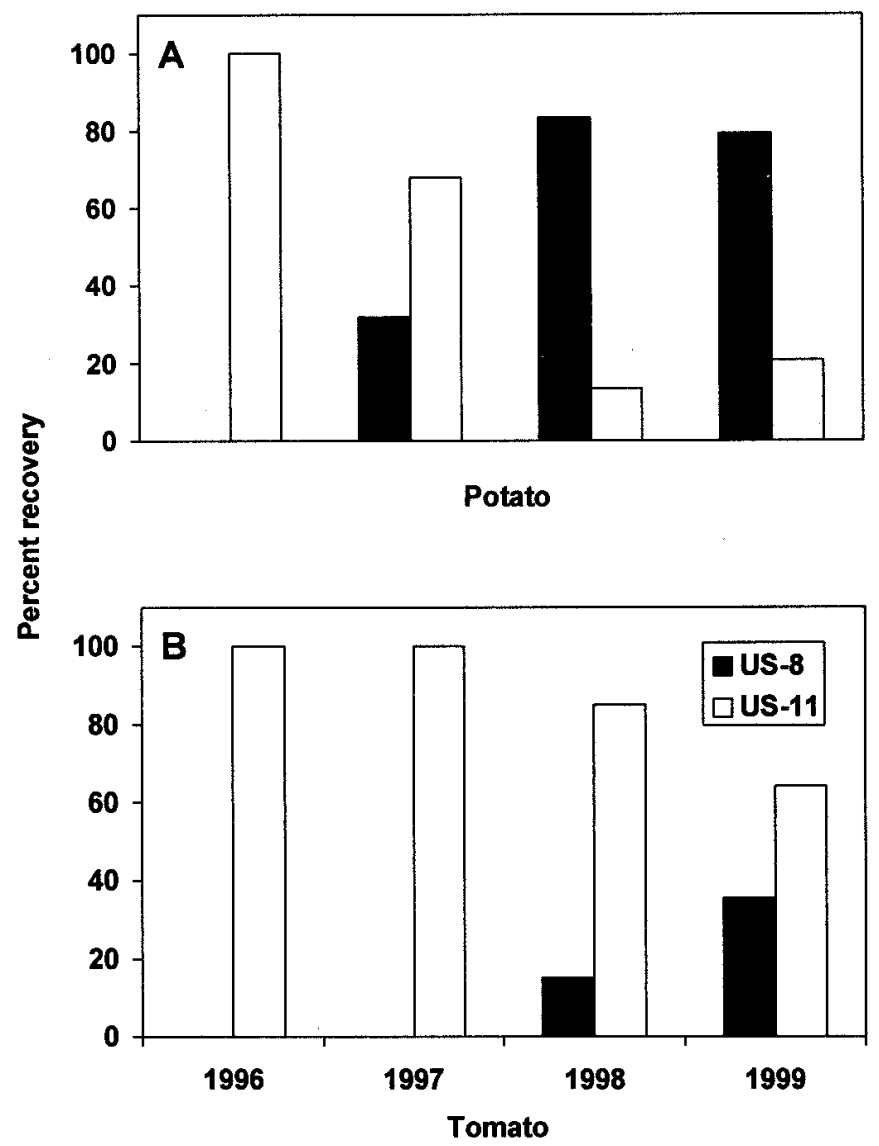

Fig. 2. Percent recovery of US-8 and US-11 genotypes of Phytophthora infestans from A, potato and B, tomato, 1996 to 1999. The 1996 and 1997 data are from Dorrance et al. (8).
Andrivon (1), in a study of $P$. infestans populations worldwide, found that the rarest virulence genes were found in highly complex races. The detached leaf assays of western Washington isolates from 1996 to 1999 revealed the virulence factor for R8 in 17 of 109 isolates $(16 \%)$ and only one of these isolates had less than 4 virulence factors. In addition, the virulence factor for R9 was found in 4 of 109 isolates (4\%), and all of the isolates carried at least 10 virulence factors. Świezyński et al. (49) evaluated data on the reaction of potato differentials to over 5,000 isolates of $P$. infestans from various parts of the world, and found the resistance of differentials R5, R8, and R9 was overcome least frequently. Our results, with the exception of R5, which occurred in 103 of 108 isolates $(95 \%)$, are similar.
A

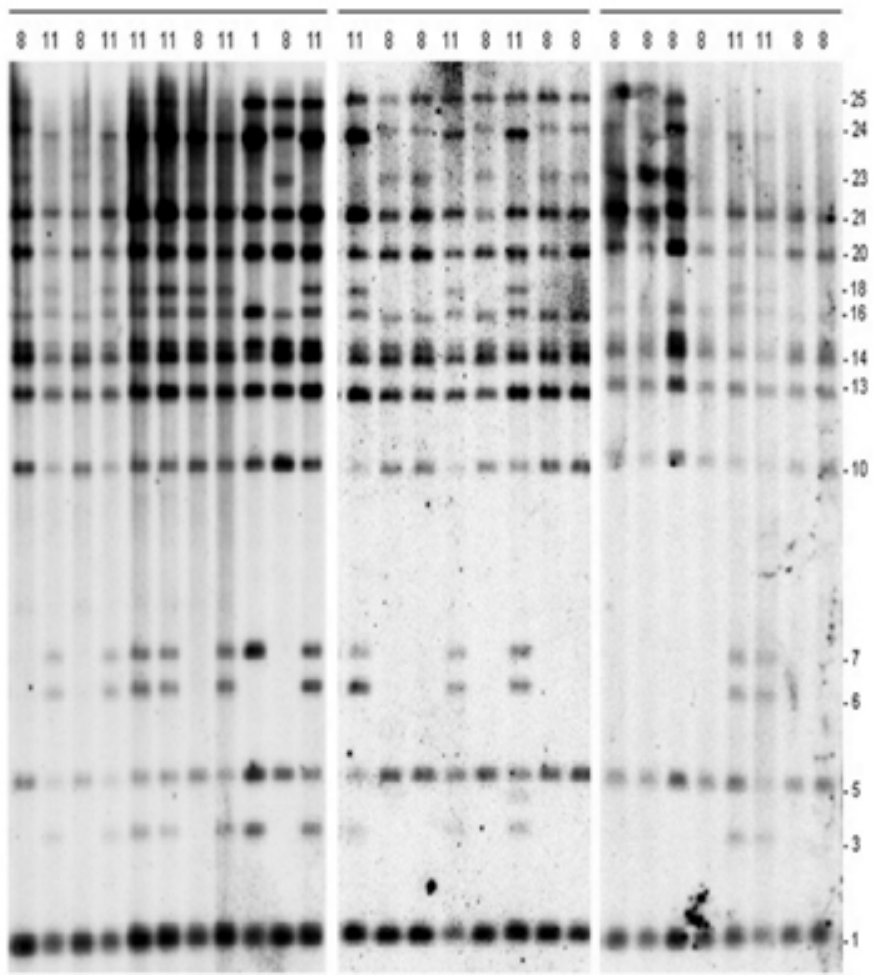

Fig. 3. DNA fingerprint patterns of Phytophthora infestans using probe RG57. Column headings A, B, and C represent 1997, 1998, and 1999 isolates collected in western Washington, respectively. Numbers over each lane correspond to genotypes described in Table 1 (lanes 9, 10, and 11 in column A represent US-1, US-8, and US-11 standards, respectively). Band numbers are indicated at right.

TABLE 3. Complex virulences among a subset of 95 isolates of Phytophthora infestans isolates collected from western Washington during 1996 to $1999^{\mathrm{a}}$

\begin{tabular}{lcccccccc}
\hline & \multicolumn{3}{c}{ US-8 $^{\mathrm{b}}$} & & \multicolumn{4}{c}{ US-11 } \\
\cline { 2 - 5 } \cline { 7 - 9 } Host & $1997^{\mathrm{c}}$ & 1998 & 1999 & & $1996^{\mathrm{c}}$ & $1997^{\mathrm{c}}$ & 1998 & 1999 \\
\hline Potato & $6 / 6$ & $17 / 17$ & $6 / 6$ & & $20 / 22$ & $11 / 12$ & $6 / 6$ & $1 / 1$ \\
Tomato & - & $1 / 1$ & $3 / 3$ & & $5 / 6$ & $5 / 10$ & $3 / 3$ & $3 / 3$ \\
Other hosts $^{\mathrm{d}}$ & - & $1 / 1$ & $1 / 1$ & & $2 / 2$ & - & - & $5 / 5$ \\
\hline
\end{tabular}

${ }^{a}$ Isolates with $\geq 4$ virulence factors determined by detached potato leaflet assays as described by Dorrance et al. (8) and Tooley et al. (51). - = genotype not recovered. Data are reported as number of isolates with designated number of virulence factors/total number of isolates tested.

${ }^{b}$ U.S. genotype designations sensu Goodwin et al. (20). US-8 genotype not detected in 1996.

${ }^{c}$ Data from Dorrance et al. (8).

${ }^{\mathrm{d}}$ Other hosts: bittersweet (Solanum dulcamara), hairy nightshade (S. sarrachoides), petunia (Petunia hybrida), potato vine (S. crispum), and yellow currant tomato $=$ Lycopersicon pimpinellifolium . 
In addition to detached leaf assays, we used potato R-gene differentials planted near germ plasm evaluation trials located at WSU-Mount Vernon REU to regularly monitor the virulences present in the field population of $P$. infestans. The reactions of the potato differentials in our laboratory virulence assay compared favorably with results on differentials planted in the field. Only two isolates obtained from R8 and R9 differentials planted in the field in 1998 proved nonpathogenic on detached leaflets of the R8 and R9 differentials in the laboratory. Goodwin et al. (22) obtained US-8 isolates from naturally infected tomato that were rated nonpathogens of tomato in greenhouse studies. We recommend that a complete set of R-gene differentials be used as a reference point for late blight evaluations of germ plasm done in field settings year after year. A similar recommendation was made by Simmonds and Wastie (45).

Evidence for complex virulence established and maintained in western Washington populations of $P$. infestans, coupled with an environment conducive to late blight, make this a desirable location for evaluating both potato and tomato germ plasm for durable resistance to the disease. Complex and naturally occurring pathotypes of $P$. infestans have been utilized repeatedly for infections in the field trials $(4,9,25,27-31)$. The persistence of these complex pathotypes, endemic to the region, may ensure successful late blight evaluations in the future.

\section{ACKNOWLEDGMENTS}

This research was supported, in part, by grants from the National Potato Council. We thank A. Dorrance, L. du Toit, D. Johnson, and M. Powelson for their critical reading of the manuscript; A. Dorrance, C. Trout-Groves, and D. Johnson for technical advice; B. Gundersen and E. Vestey for technical assistance; and Mountain View Veterinary Clinic, Mount Vernon, WA, for use of its darkroom. Plant Pathology new series 0318, project 0306, Washington State University, College of Agriculture and Home Economics Research Center.

\section{LITERATURE CITED}

1. Andrivon, D. 1994. Race structure and dynamics in populations of Phytophthora infestans. Can. J. Bot. 72:1681-1687.

2. Black, W., Mastenbroek, C., Mills, W. R., and Peterson, L. C. 1953. A proposal for an international nomenclature of races of Phytophthora infestans and of genes controlling immunity in Solanum demissum derivatives. Euphytica 2:173-179.

3. Chumakova, A. I., and Loktina, G. I. 1978. Racial composition of Phytophthora infestans and evaluation of potato for resistance. Zashch. Ovoshchn. Bakhchev. Kult. Kartofelya Vred. Bolezn. Sornyakov, Moscow.

4. Corsini, D., Pavek, J., Brown, C., Inglis, D., Martin, M., Powelson, M., Dorrance, A., and Lozoya-Saldaña, H. 1999. Late blight resistant potato germplasm release AWN86514-2. Am. J. Potato Res. 76:45-49.

5. Daayf, F., and Platt, H. W. 2000. Changes in metalaxyl resistance among glucose phosphate isomerase genotypes of Phytophthora infestans in Canada during 1997 and 1998. Am. J. Potato Res. 77:311-318.

6. Deahl, K. L., Inglis, D. A., and DeMuth, S. P. 1993. Testing for resistance to metalaxyl in Phytophthora infestans isolates from northwestern Washington. Am. Potato J. 70:779-795.

7. Derie, M. L., and Inglis, D. A. 1999. Complex pathotypes of Phytophthora infestans in western Washington during 1998. (Abstr.) Phytopathology 89(suppl.):S20.

8. Dorrance, A. E., Inglis, D. A., Derie, M. L., Brown, C. R., Goodwin, S. B., Fry, W. E., and Deahl, K. L. 1999. Characterization of Phytophthora infestans populations in western Washington. Plant Dis. 83:423-428.

9. Dorrance, A. E., Inglis, D. A., Helgeson, J. P., and Brown, C. R. 2001. Partial resistance to Phytophthora infestans in four Solanum crosses. Am. J. Potato Res. 78:9-17.

10. Drenth, A., Tas, I. C. Q., and Govers, F. 1994. DNA fingerprinting uncovers a new sexually reproducing population of Phytophthora infestans in the Netherlands. Eur. J. Plant Pathol. 100:97-107.

11. El-Kharbotly, A., Palomino-Sanchez, C., Salamini, F., Jacobsen, E., and Gebhardt, C. 1996. $R 6$ and $R 7$ alleles of potato conferring race-specific resistance to Phytophthora infestans (Mont.) de Bary identified genetic loci clustering with the $R 3$ locus on chromosome XI. Theor. Appl. Genet. 92:880-884.

12. Fernández, C. M. 1979. Changes in races of Phytophthora infestans
(Mont.) de Bary observed in southern Chile from 1963 to 1967. Agric. Tec. (Santiago) 39:7-10

13. Forbes, G. A., Escobar, X. C., Ayala, C. C., Revelo, J., Ordoñez, M. E., Fry, B. A., Doucett, K., and Fry, W. E. 1997. Population genetic structure of Phytophthora infestans in Ecuador. Phytopathology 87:375-380.

14. Fry, W. E., and Goodwin, S. B. 1997. Re-emergence of potato and tomato late blight in the United States. Plant Dis. 81:1349-1357.

15. Fry, W. E., Goodwin, S. B., Matuszak, J. M., Spielman, L. J., Milgroom, M. G., and Drenth, A. 1992. Population genetics and intercontinental migrations of Phytophthora infestans. Annu. Rev. Phytopathol. 30:107-129.

16. Gavino, P. D., Smart, C. D., Sandrock, R. W., Miller, J. S., Hamm, P. B., Yun Lee, T., Davis, R. M., and Fry, W. E. 2000. Implications of sexual reproduction for Phytophthora infestans in the United States: Generation of an aggressive lineage. Plant Dis. 84:731-735.

17. Goodwin, S. B. 1997. The population genetics of Phytophthora. Phytopathology 87:462-473.

18. Goodwin, S. B., Cohen, B. A., Deahl, K. L., and Fry, W. E. 1994. Migration from northern Mexico as the probable cause of recent genetic changes in populations of Phytophthora infestans in the United States and Canada. Phytopathology 84:553-558.

19. Goodwin, S. B., Drenth, A., and Fry, W. E. 1992. Cloning and genetic analyses of two highly polymorphic, moderately repetitive nuclear DNAs from Phytophthora infestans. Curr. Genet. 22:107-115.

20. Goodwin, S. B., Smart, C. D., Sandrock, R. W., Deahl, K. L., Punja, Z. K., and Fry, W. E. 1998. Genetic change within populations of Phytophthora infestans in the United States and Canada during 1994 to 1996 : Role of migration and recombination. Phytopathology 88:939-949.

21. Goodwin, S. B., Sujkowski, L. S., Dyer, A. T., Fry, B. A., and Fry, W. E. 1995. Direct detection of gene flow and probable sexual reproduction of Phytophthora infestans in northern North America. Phytopathology 85:473-479.

22. Goodwin, S. B., Sujkowski, L. S., and Fry, W. E. 1995. Rapid evolution of pathogenicity within clonal lineages of the potato late blight disease fungus. Phytopathology 85:669-676.

23. Goodwin, S. B., Sujkowski, L. S., and Fry, W. E. 1996. Widespread distribution and probable origin of resistance to metalaxyl in clonal genotypes of Phytophthora infestans in the United States and western Canada. Phytopathology 86:793-800.

24. Gudmestead, N. C., and Secor, G. A. 1999. Managing fungal diseases of potato. Can. J. Plant Pathol. 21:213-221.

25. Gundersen, B., Inglis, D., Porter, L., Miller, J., Johnson, D., and Brown, C. 2000. Comprehensive laboratory and field assessment of resistance to Phytophthora infestans derived from Solanum hougasii in a segregating breeding population. (Abstr.) Am. J. Potato Res. 77:399.

26. Hahn, E., Henniger, H., and Oertel, H. 1973. Das Auftreten physiologischer Rassen von P. infestans (Mont.) de By. im Jahre 1970 auf dem Gebiet der DDR. Arch. Phytopathol. Pflanzenschutz 9:105-112.

27. Inglis, D. A., Dorrance, A. E., Gundersen, B., Corsini, D., and Pavek, J. 1997. Evaluation of potato clones for resistance to late blight, 1996. Biol. Cult. Tests 12:90.

28. Inglis, D., Gundersen, B., Derie, M., and Vestey, E. 1999. Evaluation of tomato cultivars for resistance to late blight, 1998. Biol. Cult. Tests 14:117.

29. Inglis, D., Gundersen, B., Vestey, E., and Corsini, D. 1999. Evaluation of potato germplasm for resistance to late blight, 1998. Biol. Cult. Tests $14: 103$.

30. Inglis, D. A., Johnson, D. A., Legard, D., Fry, W. E., and Hamm, P. B. 1996. Relative resistances of potato clones in response to new and old populations of Phytophthora infestans. Plant Dis. 80:575-578.

31. Inglis, D., Vestey, E., Derie, M., Gundersen, B., and Creel, V. 2000. Evaluation of heirloom tomato cultivars for resistance to late blight. Biol. Cult. Tests 15:125

32. Kadish, D., and Cohen, Y. 1992. Overseasoning of metalaxyl-sensitive and metalaxyl-resistant isolates of Phytophthora infestans in potato tubers. Phytopathology 82:887-889.

33. Koh, Y. J., Goodwin, S. B., Dyer, A. T., Cohen, B. A., Ogoshi, A., Sato, N., and Fry, W. E. 1994. Migrations and displacements of Phytophthora infestans populations in east Asian countries. Phytopathology 84:922-927.

34. Large, E. C. 1940. The Advance of the Fungi. Dover Publications Inc., New York.

35. Li, X., van Eck, H. J., Rouppe van der Voort, J. N. A. M., Huigen, D.-J., Stam, P., and Jacobsen, E. 1998. Autotetraploids and genetic mapping using common AFLP markers: The $R 2$ allele conferring resistance to Phytophthora infestans mapped on potato chromosome 4. Theor. Appl. Genet. 96:1121-1128.

36. Malcolmson, J. F., and Black, W. 1966. New R genes in Solanum demissum Lindl. and their complementary races of Phytophthora infestans (Mont.) de Bary. Euphytica 15:199-203.

37. Mosa, A. A., Kobayashi, K., Ogoshi, A., Kato, M., and Sato, N. 1993. Isoenzyme polymorphism and segregation in isolates of Phytophthora 
infestans from Japan. Plant Pathol. 42:26-34.

38. Muller, H. J. 1964. The relationship of recombination to mutational advance. Mutat. Res. 1:2-9.

39. Niederhauser, J. S., Alvarez-Luna, E., and Mackenzie, D. R. 1996. RETONA a new strategy in the control of potato late blight. Am. Potato J. 73:225-229.

40. Niederhauser, J. S., and Cobb, W. C. 1959. The late blight of potatoes. Sci. Am. 200:100-112.

41. Pietkiewicz, J. B. 1978. Pathogenic variation among field isolates of Phytophthora infestans. Phytopathol. Z. 93:289-294.

42. Ross, H. 1986. Potato breeding-problems and perspectives. J. Plant Breed. Suppl. 13.

43. Schöber, B. 1975. Das Aufreten von Pathotypen von Phytophthora infestans (Mont.) de Bary in der Bundesrepublik Deutschland. Potato Res. 18:130-132.

44. Shattock, R. C., Janssen, B. D., Whitbread, R., and Shaw, D. S. 1977. An interpretation of the frequencies of host specific phenotypes of Phytophthora infestans in North Wales. Ann. Appl. Biol. 86:249-260.

45. Simmonds, N. W., and Wastie, R. L. 1987. Assessment of horizontal resistance to late blight of potatoes. Ann. Appl. Biol. 111:213-221.

46. Sujkowski, L. S. 1989. Variability in virulence and the race concept in Phytophthora infestans (Mont.) de Bary. Acta Mycol. 25:145-157.

47. Sujkowski, L. S., Goodwin, S. B., Dyer, A. T., and Fry, W. E. 1994. Increased genotypic diversity via migration and possible occurrence of sexual reproduction of Phytophthora infestans in Poland. Phytopathology 84:201-207.

48. Sukjowski, L. S., Goodwin, S. B., and Fry, W. E. 1996. Changes in specific virulence in Polish populations of Phytophthora infestans:
1985-1991. Eur. J. Plant Pathol. 102:555-561.

49. Świezyński, K. M., Domański, L., Zarzycka, H., and ZimnochGuzowska, E. 2000. The reaction of potato differentials to Phytophthora infestans isolates collected in nature. Plant Breed. 119:119-126.

50. Swiszczewska, J., Perez, B., and Piotrowski, W. 1974. Rasy fizjologiczne Phytophthora infestans wystepujace naziemniakach w 1973 r. Z. Prac. 1 Ziem. 3:10-13.

51. Tooley, P. W., Sweigard, J. A., and Fry, W. E. 1986. Fitness and virulence of Phytophthora infestans isolates from sexual and asexual populations. Phytopathology 76:1209-1212.

52. Tuite, J. 1969. Plant Pathological Methods. Burgess Publishing Co., Minneapolis, MN.

53. Turkenstein, L. J. 1993. Durable resistance of potatoes against Phytophthora infestans. Pages 115-124 in: Durability of Disease Resistance. T. H. Jacobs and J. E. Parlevliet, eds. Kluwer Academic Publishers, Dordrecht, the Netherlands.

54. Umaerus, V. 1967. Rasinventering av potatisbladmögel 1965-66. Potatis 1967:41-43. Sver. Potatisodlares Riksförbund, Stokholm, Sweden.

55. Umaerus, V., Umaerus, M., Erjefält, L., and Nilsson, B. A. 1983. Control of Phytophthora by host resistance: Problems and progress. Pages 315326 in: Phytophthora Its Biology, Taxonomy, Ecology and Pathology. D. C. Erwin, S. Bartnicki-Garcia, and P. H. Tsao, eds. The American Phytopathological Society, St. Paul, MN.

56. Van der Plank, J. E. 1968. Disease Resistance in Plants. Academic Press, New York.

57. Wastie, R. L. 1991. Breeding for resistance. Adv. Plant Pathol. 7:193-224.

58. Weising, K., Nyboom, H., Wolff, K., and Meyer, W. 1995. DNA Fingerprinting in Plants and Fungi. CRC Press, Boca Raton, FL. 